\title{
Las historias que dejó María: Educators and Researchers Bearing Witness to the Coloniality of Displacement
}

\author{
Astrid Sambolín Morales, University of Colorado Boulder \\ Molly Hamm-Rodríguez, University of Colorado Boulder \\ Bethzaida Morales Rivera, Osceola High School \\ Jasmin Nuñez Tejada, Gateway High School \\ Manuel Hernandez, Osceola High School \\ Myrmarie A. Graw-Gonzalez, Gateway High School
}

\begin{abstract}
Astrid Sambolín Morales is a Ph.D. candidate at CU Boulder's School of Education. She received her M.A. in English Education from the University of Puerto Rico Mayagüez campus and taught writing and ESL classes on the island before beginning her doctoral studies. Her research with Puerto Rican communities draws from critical theories of race, critical pedagogy, and disaster research.
\end{abstract}

Molly Hamm-Rodríguez is a Ph.D. candidate in the Equity, Bilingualism and Biliteracy program in the School of Education at the University of Colorado Boulder. She was a Community-Based Research Fellow through CU Engage, and her dissertation research in the Dominican Republic focuses on the intersections of language, literacy, and political economy.

Bethzaida Morales Rivera is a native New Yorker by birth and Puerto Rican by heart and heritage. Her parents came to New York on the Marine Tiger and instilled a passion for the island and education. She graduated from Mercy College with a B.S. in Sociology. She is the ESOL Education Specialist at Osceola High School in Kissimmee, Florida and has been a bilingual educator for 30 years. Her greatest pleasure as a teacher is that moment when the light shines in a student's eyes and they understand.

Jasmin Nuñez Tejada has been an educator for 19 years and currently serves as an Educational Media Specialist at Gateway High School in Kissimmee, Florida. This role allows her to reach, help, and connect with all students, regardless of their grade levels, behaviors, and backgrounds. She is committed to improving the lives of each and every one of her students.

Manuel Hernandez was born and raised in New York. He completed his B.A. at the University of Puerto Rico Río Piedras and his master's at Herbert H. Lehman College in New York. He is an edupreneur, author of four books, and founder of Coming to America, a successful ESL college and career educational program in Florida.

Myrmarie A. Graw-Gonzalez is an educator and historian currently pursuing a career in school administration. She believes in the power of education and hard work, helping students overcome the socio-emotional barriers that impede academic learning. She is currently serving at Gateway High School in Kissimmee, Florida as the MTSS coach, Seniors' coach, Social Studies Academic coach, and AP test coordinator.

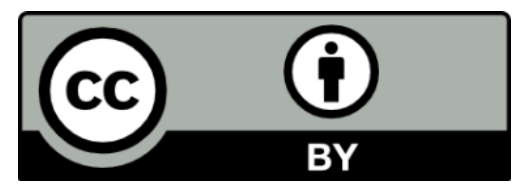

See: https://creativecommons.org/licenses/by/4.0/ 


\begin{abstract}
This article centers the experiences of two university researchers in Colorado and four public school educators from Florida as they engaged in a dialogic process of counter-storytelling to reject one-dimensional narratives and embrace contradictions and vulnerabilities throughout the process. The authors speak against the deficit stories and colonizing practices that have affected Puerto Rico and Puerto Ricans pre- and post-Hurricane María. This collaborative project humanizes the ongoing experiences of multiple displacements resulting from U.S. colonialism, racism, white supremacy ideologies, and unnatural disasters. Using a series of letters as the basis for reflection, we trace three major themes across our collaborative sense-making: (1) a desire to resist systems of white supremacy and coloniality by positioning teachers, displaced students, and their families as agents rather than victims; (2) a sense of (un)belonging that transcends or exists beyond the storm's landfall; and (3) the power of counter-storytelling as a humanizing, liberating act.
\end{abstract}

Keywords: counter-storytelling; displacement; Hurricane María; coloniality; humanizing research 


\title{
Las historias que dejó María: Educators and Researchers Bearing Witness to the Coloniality of Displacement
}

\author{
Astrid Sambolín Morales, University of Colorado Boulder \\ Molly Hamm-Rodríguez, University of Colorado Boulder \\ Bethzaida Morales Rivera, Osceola High School \\ Jasmin Nuñez Tejada, Gateway High School \\ Manuel Hernandez, Osceola High School \\ Myrmarie A. Graw-Gonzalez, Gateway High School
}

\begin{abstract}
What Brought Us Together
In September 2017, Hurricane María devastated the island of Puerto Rico, displacing 160,000 Puerto Ricans and forcing 11,500 students and their families to relocate to Central Florida (Hinojosa, Román, \& Meléndez, 2018; Meléndez \& Hinojosa, 2017). Before the storm's landfall, a variety of interconnected factors-Puerto Rico's status as a colonial commonwealth, Puerto Ricans' U.S. citizenship, the island's declining economy, and Florida's economic boom in the 1990s — had already contributed to steady displacement from Puerto Rico and had established Florida as home to the second largest Puerto Rican population in the U.S. mainland. After the storm, with funding from a Quick Response grant from CU Boulder's Natural Hazards Center, Astrid, a Puerto Rican woman and doctoral student, and Molly, a white female doctoral student, began a pilot study (see Appendix A) to learn about the stories and experiences of teachers supporting Puerto Rican students and families displaced to Orlando, Florida and nearby Kissimmee. This geographic location was selected due to the presence of a well-established Puerto Rican community and the metropolitan area's designation as a FEMA relocation site. Findings from this pilot study highlighted teachers' experiences and suggested, among other things, that 1) teachers desired additional resources to provide quality language supports and services to students displaced from Puerto Rico after the storm; 2) schools experienced a shortage of bilingual teachers, paraprofessionals, and counselors, and; 3 ) Puerto Rican and Latinx teachers played an active role in holistically supporting students and mediating differences between the school culture in Puerto Rico and mainland U.S. public schools.

After listening to teachers' compelling stories in the first stage of research, Astrid and Molly returned to Colorado with a vision for moving beyond transactional research (where interviews would merely serve as data for a research report) to engage in humanizing research that would build solidarity with teachers and continue to highlight and support their ongoing work with students in Florida. As a result, Astrid and Molly applied to participate in the URBAN Conference on Place and Displacement, which fostered intersectional approaches and equitable partnerships to address displacement across the U.S. As awardees, this project received community-based research funding to develop a second phase of this project: long-term collaboration with some of the teachers interviewed during the initial fieldwork. Astrid and Molly reached out to the two high schools with whom they developed the strongest relationships and invited interested teachers to collaborate and develop a teaching unit that would provide a platform for displaced Puerto Rican students to share their stories pre- and post-Hurricane María. Such a project would provide spaces for students to resist dominant discourses portraying displaced Puerto Ricans as either ungrateful "immigrants" or "quitaos" (i.e., individuals unwilling to stay and endure hardship to rebuild the island). As a result, the following
\end{abstract}


participants with classroom and instructional leadership roles joined this endeavor: Myrmarie Graw, Manuel Hernández, Bethzaida Morales Rivera, and Jasmin Nuñez Tejada.

The collaborative project was intended to support students as they explored shifting meanings of home and place in Florida and Puerto Rico as a result of their displacement, exploring both physical/geographical and emotional/affective ties while telling their stories on their own terms. Additionally, this collaborative second phase would create a space where we could reflect collectively on events after the storm and envision alternative futures in our personal lives and professional roles. As a result, the six of us met in Colorado at the URBAN Conference to discuss the objectives and logistics of planning for the unit we wanted to create for students. After collectively looking at data from the pilot study carried out by Astrid and Molly, we all agreed that one crucial shared commitment was the desire to engage in humanizing research that opens "a space in which individuals and communities can work collaboratively toward more fully realizing their human potential" (Irizarry \& Brown, 2014, p. 65). We also agreed that another key component in fulfilling this goal - to realize our and our students' human potential - is to disrupt and reject deficit stories and colonizing practices that have affected Puerto Ricans in general and displaced Puerto Ricans in particular. These deficit stories, circulated in national media and shared by participants in the initial pilot study, included portrayals of Puerto Ricans as victims passively waiting for and exclusively relying on U.S. assistance pre- and post- Hurricane María. These stories also portrayed Puerto Ricans as taking "the easy way out" or wanting "a free ride" from the U.S. government by moving to the mainland U.S. in search of better economic opportunities. Ultimately, our group committed to the importance of having our students' and our own voices heard as we bore witness to the intersections of displacement and "the social forces of five centuries of colonization by Spain and then the United States... [which] construct the island [of Puerto Rico] as a site of extraction, with its people at times invisible and at others dispensable" (Lloréns, 2018, p. 158). To reach our goal and conduct humanizing research, we shared our own experiences and reflected on the commitments we brought to this collaborative space through the letters presented in this piece.

\section{Puerto Rico, Colonialism, and Vulnerability}

Astrid and Molly recognize that part of the need for counter-storytelling in this project is due to the rampant ignorance, misinformation, and apathy across the U.S. in relation to Puerto Rico. Thus, we feel a need to further contextualize Puerto Rican displacement, citizenship, and coloniality for our readers. Puerto Rico became a U.S. colony in 1898, allowing the U.S. to retain control over the island and use "whiteness [a]s an essential qualification for citizenship" (NakanoGlenn, 2002, p. 158) to exclude Puerto Ricans, as racialized subjects, from formal citizenship. Even after Puerto Ricans became U.S. nationals through the 1917 Jones Act and after Puerto Rico obtained limited autonomy as a commonwealth in 1952, white supremacy ideologies have continued to produce exclusion and second-class citizenship — through colonialism and racismfor Puerto Ricans. Thus, Puerto Rico and Puerto Ricans have been surviving amidst statesanctioned conditions of vulnerability long before Hurricane María's landfall. As Lloréns (2018) notes,

In Puerto Rico, societal vulnerabilities result from a long history of colonial subjugation, economic hardship, environmental injustice, infrastructural neglect, and, at the local island level, a broken rule of law. Hurricane María's winds exposed the vulnerabilities created by ubiquitous socioeconomic inequality and neglect of the island's rural regions, like fault lines buried under shallow soils. (p. 156) 
Lloréns (2018) identifies the 1980s as a critical decade when Puerto Rico's vulnerability increased dramatically. This period was marked by social problems such as the increase of crime, poverty, and unemployment as well as greater socio-economic disparity, and the solidification of privatization (the transfer of businesses, industries, or services from government ownership to private ownership). For example, in Puerto Rico, "the government acts as the main channel for the mass privatization of public services. In many ways the government is perceived as the main partner to private industry, facilitating its entry into local markets at the expense of the needs of the citizenry" (Lloréns, 2014, p. 190). Thus, privatization, debt, and other forms of predatory capitalism have contributed to the conditions that have long forced displacement and created social abandonment in Puerto Rico (Bonilla \& LeBrón, 2019).

It is clear, then, that these conditions were only exacerbated after Hurricane María's landfall on September 20, 2017. Media, government agencies, and the private sector made use of a particular narrative, what Steinberg (2006) calls "calamity etiquette", to position natural disasters as inevitable acts of nature impossible to fully prepare for or predict. Through this framing, the government and private sector's role in producing vulnerability are conveniently omitted and the most vulnerable (e.g., those without land titles to access FEMA resources) are instead disciplined by colonial disaster management institutions (Molinari, 2019). Thus, disaster results from a combination of socio-economic, racial, and political inequities as well as human intervention that have worked together to expose certain groups to greater risk during and after an event (Esnard \& Sapat, 2014; Fothergill \& Peek, 2004, 2015; Steinberg, 2006).

\section{Our Goal}

This paper centers our team's experiences as university researchers and public school educators engaging in a dialogic, collaborative process as we planned our work with students. Dialogic, collaborative processes allow different voices and experiences to provide multiple perspectives in the co-construction of meaning (Paulus, Woodside \& Ziegler, 2008). Moreover, as a method to highlight and honor our different voices, we engaged in counter-storytelling, or the telling of stories that challenge dominant narratives which treat the experiences and/or viewpoints of white individuals, men, the middle and/or upper class, and heterosexuals as the norm (Solórzano \& Yosso, 2002). This process allowed us as a group to disrupt deficit storytelling frameworks while also promoting transformative praxis, or action and reflection, through relational practices of self-empowerment. In this article, we first share the group's counter-stories in the form of individual letters written to a recipient of our choosing (teachers, researchers, and/or students of color), and then we end with a discussion of the common themes we all saw emerge across letters: (1) a desire to resist systems of white supremacy and coloniality by positioning displaced students, families, and teachers as agents rather than victims, (2) a sense of (un)belonging that transcends the storm, and (3) the power of counter-storytelling as a humanizing, liberatory act. Through this writing and reflection process, our collective hope is to contribute toward the advancement of humanizing scholarship by centering "non-universal, localized truths [that] constitute valid alternative ways of knowing" (Baldwin \& Huggins, 1995, p. 8).

\section{What Guides Our Research}

The dialogic process all authors engaged in was born from our struggle to both stand in solidarity with students and other Puerto Ricans when telling their stories as well as the need to support ourselves and each other as we engaged in the research process, bore witness to injustices 
and racism, and shared our own counter-stories. By using counter-stories, we hope to challenge majoritarian narratives that treat the experiences and/or viewpoints of individuals from minoritized communities as outside the norm (Solórzano \& Yosso, 2002). As Matsuda (1995) argues, "those who have experienced discrimination speak with a special voice to which we should listen" (p. 63). This stance centers the voices of organic intellectuals or "grass roots philosophers who are uniquely able to relate theory to the concrete experience of oppression" (Matsuda, 1995, p. 63).

Through this approach, we strive to collectively build community and put a "human and familiar face to educational research and practice" (Elenes \& Delgado-Bernal, 2010, p. 70). This process of counter-storytelling "help[s] strengthen [the] traditions of social, political, and cultural survival and resistance" (Solórzano \& Yosso, 2002, p. 32) that people of color develop, embody, and draw from in their everyday lives. Finally, our piece is heavily informed by Michelle Fine's (2017) work, which advocates for research that illuminates how the stories and voices of people from minoritized communities reflect systemic problems such as racism and white supremacy, among others. Through what Fine (2017) calls a radical, critical approach to research, participants work together to resist "othering" while centering their whole selves.

For our group, this dialogic process required co-presence - an opportunity to sit, think, and theorize together - because we understand that our social bodies are integral to how we experience and understand the world (Willis \& Trondman, 2000). We also follow calls for reflexivity in research by placing ourselves in the stories we tell and locating ourselves in relation to the topic of inquiry (Abu-Lughod, 2000). In addition, we simply take each other seriously (Astuti, 2017) in this work, acknowledging the multiple sources of knowledge and the different ways of knowing we all contribute to this collective process.

Finally, by developing counter-stories as part of our collective sensemaking, we hope to challenge traditional, positivist research paradigms that emphasize universality and generalizability, instead "embrac[ing] a diversity of standards for scientific truth and validity" (Baldwin \& Huggins, 1995, p. 4). This approach centers the equally valuable knowledges and experiences from those often silenced in research. In other words, we aim to treat the unique knowledges, experiences, and truths from members of marginalized, minoritized communities as not simply equally valid and valuable in terms of methodology, but as superior in the pursuit of humanizing research that pushes against inequity and dehumanization. We thus are inspired by Cahill's (2004) work on collaborative research, which places "emotional motivation; the politicization of personal experience; and the power of speaking back with research" (p. 273) at the forefront. We carry out a collaborative research process by bridging multiple worlds of theory, practice, and experience. Furthermore, we hope our work challenges educational research that, either consciously or unconsciously, "has played a deleterious role in perpetuating and refreshing colonial relationships among people, practices and land" (Patel, 2016, p. 30) within a system of racism that upholds, and indeed requires, the subordination and colonization of people of color.

\section{How We Came Together}

By applying to The URBAN Conference on Place and Displacement, Astrid and Molly were able to provide travel funds for all research members to participate in a two-day convening designed to facilitate collaboration among our research team as well as across the geographically and thematically different research teams participating in the project. During these two days, our team (consisting of two doctoral students from the University of Colorado Boulder and four public school educators from Kissimmee, Florida) attended workshops and engaged in data 
analysis sessions where we discussed salient excerpts from the pilot study corpus and emerging themes that surfaced. The pilot study corpus included individual and group interviews with school administrators, teachers, and district personnel as well as a focus group with mothers. As we reviewed the data together, we created counterpublics or spaces where we could "oppose stereotypes and assert novel interpretations of [our] own shifting identities, interests, and work" (Weis \& Fine, 2001, p. 499), thereby making connections between the data and our personal experiences as teachers, researchers, Latinx individuals, and/or allies.

As part of our method (see Appendix B), we moved beyond the data collected in the pilot and leveraged our emotions and perspectives "in the moment" to write counter-stories using Solórzano \& Yosso's (2002) approach to creating stories. However, instead of creating characters and placing them in a particular social, political, and/or cultural context to address colonialism, displacement, and racism, our counter-stories materialized as letters that each participant wrote to a recipient of their choosing. Using the prompt "I probably shouldn't be telling you this, but...."1 encouraged us all to think of loving, honest responses challenging majoritarian narratives about teaching, teachers, Puerto Ricans, and/or displaced Puerto Rican students in the aftermath of Hurricane María (Solórzano \& Yosso, 2002). We read our stories aloud to each other and had a discussion about commonalities across our narratives. A few months after writing our letters, we each re-read the counter-stories on our own and wrote responses recording how we felt after revisiting them and identifying salient ideas across letters. These responses helped us agree on three major themes across our collective sense-making, which we will share in the discussion section.

This paper includes the six letters we wrote as a team during the conference. By including the text from the letters, we center the feelings of anger, frustration, sadness, and hope embodied by each of us that day. We thus highlight how emotions and relationality are valuable, legitimate, and necessary components of our counter-stories and our envisioning of alternative futures. These letters collectively expose our honest reflections about displacement, colonialism, and racism, resisting one-dimensional narratives and embracing the contradictions and vulnerabilities inherent in counter-storytelling. Through this process, we found that our emotional (and sometimes physical) proximity to the research increases validity by providing "truer and richer data than the model of the somewhat detached, neutral researcher" (Paris, 2011, p. 138). As a team, we were thus able to move beyond the limitations of the findings revealed in the pilot study to analyze the three additional themes discussed below.

\section{"I Shouldn't Be Telling You This, But..."}

\section{Bethzaida to a student Maybe I shouldn't tell you this, but it is important that you know.}

There will always be someone to make you feel inferior. It will be through a simple gesture, a word, or an overt action. Don't allow it. You come from a race of warriors. You are stronger than the person trying to make you feel inferior. Pity that ignorance or insecurity. You have arrived here with a purpose. You will move forward without a handout and sometimes without support.

\footnotetext{
${ }^{1}$ We want to thank Michelle Fine, Distinguished Professor at the CUNY Graduate Center, for mentoring our research team, creating the prompt to which we responded, and guiding this reflexive process.
} 
Or so you think. Look closely. There are so many people willing to help you succeed. Ask and someone will reach out. Never fear the future. You may feel out of control, but you're not. Trust in yourself, your talents, and find the strength and character or pride you need to make it. Everyone will have a critic. Look at the politicians. Do their critics stop them? No. Let no one stand in the way of your success, not even yourself.

Sí, tú puedes. Yo voy a ti.

\section{Manuel to a student \\ Dear Juan/Estimado Juan,}

Wow! How are you? ¿Cómo estás? It's the year 2075. Maybe I shouldn’t tell you this, but I know you will face difficulties beyond your wildest imagination. No sé si tengas que traducir este mensaje, pero sé que estás aquí porque te trajeron. You are here because you were brought here. Sientes que los tuyos te traicionaron, but I also know that you have unlimited potential. Tienes un potencial sin límites.

You will face discrimination, racism, and guilt, but you have the resources for success. Te enfrentarás a un sistema discriminatorio y racista, pero tienes todos los recursos para el éxito. You come from a rich and diverse culture y esa cultura rica con tanta diversidad te ayudará poco a poco a entender que si te enfocas, aún dentro de lo difícil que sea tu situación, vas a perseverar.

You need to know who you are, and that will help you understand and move forward. Tienes que entender quién eres y tu identidad te ayudará a moverte hacia adelante. Second, you come from a very diverse heritage, and your heritage will unlock the keys to the future. Many have walked your path before. Just 30 years ago, we inaugurated our first Hispanic President. Necesitas mirar al espejo de la dignidad de la historia y decidir que vas a triunfar. No hay mucho más que pueda decirte. There is not much more that I can say that will help you succeed and reach higher levels of understanding. Do not let anyone determine who you are and where you are going.

¡Gracias por escucharme! Thanks for listening! My great-great-grandchildren will hear about your success and contribution to humankind!

¡Exito!

Myrmarie to a teacher

Maybe I shouldn't say this but...

You have so many things to do and so little time to accomplish them. Plans, records, evidence, standards, observations, feedback, evaluations--there are so many strategies thrown at you. And I see you. You have struggled. You want to be that superhero that will make a difference. But every day you forget the most important thing to do: you must care. I know. I know that you do care, but I am not referring to teaching them to read, write, add, or divide numbers. I'm referring to caring about who they are. Did your student, that student, eat? Did they sleep? Did they stay up all night listening to their parents or step-parents argue while taking care of their siblings? Did they go to work to help their mom or to afford a phone that distracts them from the realities of their life? Did they get sick because they ate the unfamiliar food served in the cafeteria? Are they sad because their "future" is dependent on leaving their friends, family, and home? Have you ever looked at them? 
You are the representative of change. That child's life has completely changed, and it will be changing constantly for a long time before they find a semblance of stability. You are their only constant. They don't have a choice about being in school, in your class. It is on you to connect, engage, and care. They will learn if you care.

Jasmin to a student

Maybe I shouldn't say this...

Education is not what you have always been told. Education is not only found in a "good school" or "good neighborhood." Educated people are not only those who speak "properly," have good jobs, are well-connected, or had a "good upbringing." An educated being is more than what you've always known. Maybe I shouldn't tell you this but I feel a sense of responsibility in sharing the truth with you.

As you grow, what you think to be true will not always be true. What you think to be a dream come true will not always be the greatest dream of all. The truth is that your life will always be full of changes and, at times, you won't agree with them, feel comfortable with them, or even imagine the impact they will have on you. Changes will shape your life, your emotions, your feelings, your thoughts, and perceptions, and changes will come to affect your intentions. Changes are not always negative, and bad experiences aren't always negative. Difficult, tough experiences can actually be your biggest blessings in disguise. Being considered less than is not always the worst thing in life. Why? Well, maybe I shouldn't say this to you, but I actually prefer to be considered less than or have people doubt me so I can turn around and prove them wrong. I like to make others change their perceptions and opinions of me. I like to change what is expected of me. Change can be a powerful gift. Being an immigrant, a refugee, or a child from Puerto Rico, Dominican Republic, or Cuba isn't always bad, since the transition can bring about the biggest changes in yourself.

\section{Molly to a mother}

Maybe I shouldn't say this but...

You know more than the world will have you believe. You are already enough. Your pain is not yours alone to carry. We all bear the burden and responsibility in different ways, but you don't owe your pain to anyone. Let yourself be. Give yourself the grace to be safe, to be strong, to be vulnerable, to breathe. Be what you need to be for you and those you hold dear. Today doesn't have to be tomorrow, even as yesterday still continues to matter. Speak your truth. Your truth deserves an audience, even if that audience doesn't deserve your truth. But protect yourself. You don't have to be everything to everybody because not everybody will be everything for you. You are needed, and your way of being and moving in this world has a purpose, even when that purpose tries its best to hide itself from you. There is a past, a present, and a future that yearns for you and all that you have to offer. Even beyond this lifetime, you matter.

Astrid to her future daughter

$* * *$

I shouldn't be telling you this, but... 
You are not white, no matter what anyone back home tells you. You will grow up to be a woman of color in a world that hates people of color and thinks women are less than. You will navigate a world that will treat your home language like a dirty secret you need to hide, a defect you need to fix. Your body will be a messy text others will want to edit so it reads just right. Your opinions, your manner, the tone of your voice, the volume of your voice (inside voice, please) will all be scrutinized. If you grow up in Puerto Rico, you will be told to leave. It's too hard here, there are no opportunities, it's too dangerous (It's no wonder they don't want us. We're trash). If you grow up in the U.S., then you're not really Puerto Rican. You don't really care or know what it's like living on the island, so you don't get to have an opinion.

You belong nowhere, because you should be somewhere else. Wherever you are, wherever you go, you will be a coward, because being courageous, doing the right thing, is always the option you didn't choose. I shouldn't be telling you all this... but I am. Because this is all true, but it's also a lie. You are courageous, because every choice is a hard one. You are Puerto Rican wherever your home is. You will find a sense of belonging, because you do belong. You have so much to offer in a place that needs what you offer. "You were born at the crossroads, and you are whole." 2

\section{Making Sense of It All}

A few months after writing and sharing our letters at the URBAN Conference, all six team members digitally revisited each other's counter-stories and wrote individual reflections recording the impact that writing the letters had on us. Each team member also described common themes identified across the letters after reading them. By gathering individual and collective responses to the letters and letter-writing process, Astrid and Molly traced three major themes across our collaborative sense-making: a desire to resist systems of white supremacy and coloniality by positioning teachers, displaced students, and their families as agents rather than victims; a sense of (un)belonging that transcends or exists beyond the storm's landfall; and the power of counter-storytelling as a humanizing, liberating act.

\section{Teachers, Displaced Students, and Families as Agents Rather Than Victims}

The first major thread Astrid and Molly identified across the letters is the desire to resist racist, discriminatory, and colonial narratives that present a one-dimensional story about Puerto Ricans in general and displaced Puerto Ricans in particular. As Myrmarie reflects, our collective writings highlight "the need to humanize [displaced Puerto Rican] students and not make them feel like low achievers who will put more weight on our shoulders," a narrative some teachers and administrators drew from in their interviews during the pilot study. Instead, we emphasize that it is also crucial to highlight Puerto Ricans' survivance and agency post-disaster. As Bethzaida explains:

I'm proud of the children and their parents who never gave up. The children came to school every day, although most of the time they wanted to cry because the struggle was far more than just language. I admire and respect the parents who held two jobs each to quickly stabilize their homes.... I am so proud to belong to a group of people who, despite difficulties, can see beyond the hardship and look at the possibilities. I've just returned from a trip to Puerto Rico, and what I saw warmed my heart. I saw a people rebuilding, I

\footnotetext{
${ }^{2}$ From "Child of the Americas" by Aurora Levins Morales
} 
saw new hope, I saw growth. I felt the warmth and heart only a people who know loss, oppression, and hope can emanate...I lived the spirit of Puerto Rico.

Rather than positioning displaced Puerto Ricans as passively experiencing loss, prejudice, and the indignities inherent to their experiences as colonial subjects, our counter-stories serve to highlight their agency and survivance as they strive to reconstruct their lives. As Molly argues, this collaborative, reflexive process is important since it provides "a space for self-expression without replicating transactional modes of inquiry that see students as victims rather than agents."

Our letters not only highlighted displaced Puerto Ricans' agency and strength, but they also addressed how Latinx teachers share a legacy of resistance, creativity, and survivance in the face of historically state-sanctioned violence with their students. Manuel notes:

It is mind-boggling to observe how much we strive to improve ourselves, myself included, but we forget there are so many Latinx individuals homeless, in detention centers, and wrongfully accused of crimes they did not commit. My focus is education. I have seen and observed how education can change the life of a recently arrived immigrant. Writing to Juan in 2075 made me realize that if we do not focus as a community, we are not going to be able to improve the quality of education and living for future generations.

In other words, we collectively recognize the legacy educators share with students even as we all navigate (and are complicit in) racist, discriminatory systems, including schools. Thus, we have the potential to seek avenues of liberation for ourselves and our students to dismantle existing systems of power and oppression.

\section{(Un)belonging}

Another thread across our reflections reveals a sense of (un)belonging, of existing in a liminal space where you are both an insider and outsider, which extends beyond Hurricane María and its aftermath. As previously described, Puerto Rico's status as a U.S. colony positions Puerto Ricans as racialized, second-class citizens. Moreover, economic and social factors stemming from this colonial relationship have forced Puerto Ricans to continuously cross geographic, linguistic, and cultural borders in search of often elusive stability. The original letters and subsequent responses address a sense of (un)belonging experienced both by those who moved back and forth between the mainland U.S. and the island before the storm, as well as those who were forced to leave post-María. Manuel addresses this sense of (un)belonging as a Puerto Rican who was born and spent his childhood in New York only to move to the island as an adolescent:

Coming of age in the so-called Island of Enchantment provided me with an interesting experience of living with various cultures and trying hard to make sense of living in a geographical space other than my place of origin. I worry a lot about what dreams may come for Latinos in the United States. I worry about the fact that we (Latinos) are so many in numbers but very ignorant concerning our present and future in this country. I have lived in 'displacement' my entire 50 plus years of age.

By occupying a liminal space where our rights as U.S. citizens are often contested and where we must navigate multiple borders throughout different stages of our lives, Puerto Ricans such as Manuel must often confront the narrow limitations of what it means to belong either on the island or the mainland.

This sense of (un)belonging, however, is amplified for those who arrived to the mainland after Hurricane María. The storm drastically changed Puerto Rico. Many displaced students and families no longer had a home to return to, even if they could go back. Bethzaida described displaced students' experiences vividly: 
Most of the students arrive with little more than the clothes they managed to salvage, leaving a life they loved and finding themselves in temporary housing. The lucky ones come to live with family, which softens the shock of leaving everything behind. The less fortunate pile into hotels along US 192 Irlo Bronson Highway until better accommodations can be arranged.

Although dominant discourses surrounding Hurricane María highlighted efforts to secure housing and basic needs for displaced students and families, these resources do little to transform displacement into feelings of being at home. As Astrid observes, they might have relocated, but they are not home." Myrmarie agrees, adding that those who relocated to Florida suffered from "a conscious or unconscious perception of inferiority, since [they]...were not part of the mainstream majority in our society. They struggled with their own identity and wondered where they belonged."

In short, for some Puerto Ricans, the coloniality of displacement produces a sense of (un)belonging across multiple locations before and after Hurricane María. However, it is important to note the letters also reflected alternative visions for the future that center Puerto Ricans' agency, creativity, and survivance. As Bethzaida wrote to her student: "There will always be someone to make you feel inferior. It will be through a simple gesture, a word, or an overt action. Don't allow it. You come from a race of warriors." Here, Bethzaida encourages youth to think intergenerationally about their legacies of strength, reframing narratives of second-class citizenship.

\section{Counter-Storytelling as a Humanizing, Liberatory Act}

The third and final connecting thread throughout our reflexive responses was that we all addressed how the act of writing counter-stories affected us as educators, researchers, and individuals. Myrmarie describes it as:

a liberation task. In my letter, I wrote with my heart. This writing process, then, became one of self-reflection... I wanted other educators to understand how important they are in our children's lives. Our actions, reactions, and commitments are the difference between easing that child's struggles or making it worse. I still believe in the power of a wellrounded and caring education. Students matter and so do we because we are one.

In Myrmarie's case, engaging in counter-storytelling allowed her to expand her understanding of her role as an educator. Students' and teachers' successes are interdependent; theirs is a bidirectional relationship where they are working and growing together. When enacted reflexively and with care, this relationship has the possibility of humanizing both teacher and student in the process.

For Jasmin, storytelling allowed her to connect with others beyond the research project: "I no longer view life's experiences as my very own, but more so, as a collection of everyone's experiences, forcing us to identify as one people regardless of circumstance." Molly also addressed the humanizing component of sharing experiences through collective counterstorytelling: "As I reread all the letters, the emotionality of the words written from different places of reflection stands out to me. I believe this collaboration, including and beyond the writing, has provided a space for anger, sadness, indignation, regret, hope, and a multiplicity of unnamed - but felt and embodied - emotions. We...view the storytelling process as a humanizing act of collective healing." In other words, this collective counter-storytelling and reflexivity allowed us to humanize ourselves and one another by foregrounding relationality, speaking our truths, and working to understand one another, even as we come from different places. As Astrid 
argues, "this collective sensemaking has proven to be a healing process. Across all the letters, I see messages that highlight people of color's strength, their worth, their dignity, and their humanity. Most importantly, I see a space to voice our humanity, our experiences, and our connections to others in our own terms."

\section{Where Do We Go From Here?}

As evidenced in the process of sharing our letters, our team envisions our contribution to public scholarship and community-based research as an act of making public our own collective counter-storytelling and reflexivity. We believe that this dual process of creating and reflecting on what we have produced not only enriches and strengthens what we have to share but also emphasizes the analytical process itself as something that is iterative, evolving, and necessarily takes place across time. Most importantly, it ensures that participants have full control over their narratives, the ways in which they are shared publicly, and the interpretations that they give both to the process of storytelling itself and the stories that emerge from that process. From mass media, the pilot study, and educators' everyday work alongside students and families, we know that those who were displaced from Puerto Rico by Hurricane María are still being subjected to scrutiny and surveillance by both residents of Florida at large as well as those who remained on the island. This collaborative project reflects efforts to humanize the ongoing experiences of multiple displacements resulting from U.S. colonialism, racism, white supremacy ideologies, and unnatural disasters. In addition, as we make connections across shared experiences, we seek to decolonize perceptions of Puerto Ricans and Puerto Rico (held by White, middle-class Americans as well as Puerto Ricans) and to contextualize the decisions made by those who have been most affected by ongoing societal vulnerabilities. 


\section{References}

Abu-Lughod, L. (2000). Locating ethnography. Ethnography, 1(2), 261-267.

Astuti, R. (2017). Taking people seriously. HAU: Journal of Ethnographic Theory, 7(1), $105-122$.

Baldwin, C., \& Huggins, D. W. (1995). The feminist perspective: Humanizing research. Retrieved from: https://files.eric.ed.gov/fulltext/ED402518.pdf

Bonilla, Y. \& Lebrón, M. (Eds.) (2019). Aftershocks of disaster: Puerto Rico before and after the storm. Haymarket Books.

Cahill, C. (2004). Defying gravity? Raising consciousness through collective research. Children's Geographies, 2(2), 273-286.

Elenes, C. A. \& Delgado-Bernal, D. (2010) Latina/o education and the reciprocal relationship between theory and practice: Four theories informed by the experiential knowledge of marginalized communities. In E.G. Murillo, S. Villenas, \& R. Trinidad Galván (Eds.), Handbook of Latinos and education (pp. 63-89). Routledge.

Esnard, A., \& Sapat, A. (2014). Displaced by disaster: Recovery and resilience in a globalizing world. Routledge.

Fine, M. (2017). Just research in contentious times: Widening the methodological imagination. Teachers College Press.

Fothergill, A., \& Peek, L. A. (2004). Poverty and disasters in the United States: A review of recent sociological findings. Natural Hazards, 32(1), 89-110.

Fothergill, A., \& Peek, L. A. (2015). Children of Katrina (First ed.). University of Texas Press.

Lloréns, H. (2018). Ruin nation: In Puerto Rico, Hurricane Maria laid bare the results of a longterm crisis created by dispossession, migration, and economic predation. NACLA Report on the Americas, 50(2), 154-159.

Lloréns, H. (2014). Imaging the great Puerto Rican family: Framing nation, race, and gender during the American century. Lexington Books.

Matsuda, M. (1995). Looking to the bottom: Critical legal studies and reparations. In K. Crenshaw, N. Gotanda, G. Peller, \& K. Thomas (Eds.), Critical race theory: The key writings that formed the movement (pp. 63-79). New Press.

Meléndez, E. \& Hinojosa, J. (2017). Estimates of post-hurricane Maria exodus from Puerto Rico. New York: Center for Puerto Rican Studies, City University of New York. Retrieved from: https://centropr.hunter.cuny.edu/sites/default/files/RB2017-01-POSTMARIA\%20 EXODUS_V3.pdf.

Nakano-Glenn, E. (2002). Unequal freedom: How race and gender shaped American citizenship and labor. Harvard University Press.

Hinojosa, J., Román, N., \& Meléndez, E. (2018). Puerto Rican post-Maria relocation by states. New York: Center for Puerto Rican Studies, City University of New York. Retrieved from: https://centropr.hunter.cuny.edu/sites/default/files/PDF/ Schoolenroll-v2-3-32018.pdf.

Irizarry, J., \& Brown, T. (2014). Humanizing Research in Dehumanizing Spaces: The Challenges and Opportunities of Conducting Participatory Action Research with Youth in Schools. In D. Paris \& M. Winn (Eds.), Humanizing research: Decolonizing qualitative inquiry with youth and communities (pp. 62-80). Sage.

Molinari, S. (2019). Authenticating loss and contesting recovery: FEMA and the politics of colonial disaster management. In Y. Bonilla \& M. LeBrón (Eds.), Aftershocks of disaster: Puerto Rico before and after the storm (pp. 153-158). Haymarket Books. 
Patel, L. (2016). Decolonizing educational research: From ownership to answerability. Routledge.

Paris, D. (2011). 'A friend who understands fully': Notes on humanizing research in a multiethnic youth community. International Journal of Qualitative Studies in Education, 24(2), 137149.

Paulus, T., Woodside, M., \& Ziegler, M. (2008). Extending the conversation: qualitative research as dialogic collaborative process. The Qualitative Report, 13(2), 226-243.

Solórzano, D. G., \& Yosso, T. J. (2002). Critical race methodology: Counter-storytelling as an analytical framework for education research. Qualitative Inquiry, 8(1), 23-44.

Steinberg, T. (2006). Acts of God: The Unnatural History of Natural Disaster in America (Second ed.). Oxford University Press.

Weis, L., \& Fine, M. (2001). Extraordinary conversations in public schools. International Journal of Qualitative Studies in Education, 14(4), 497-523.

Willis, P. \& Trondman, M. (2000). Manifesto for Ethnography. Ethnography, 1(1), 5-16. 


\section{Appendix A \\ Orlando/Kissimmee Pilot Study Methodology Overview}

\section{Research Questions}

1. What policies and programs were enacted by the district in anticipation of or in response to receiving students from Puerto Rico (including but not limited to enrollment assistance, family engagement initiatives, language services, and socioemotional support)?

2. To what extent did receiving communities respond to the disaster by enacting initiatives and programs to provide access to key social services for arriving Puerto Rican children and their families?

3. What are the perspectives and experiences of key stakeholders (e.g., district staff, administrators, teachers, and parents) related to the schooling of Puerto Rican children displaced by the hurricane, including ongoing opportunities and challenges faced?

\section{Participants}

School District (1)

- Administrators and Directors (3)

Schools (4)

- Principals and Administrators (4)

- Special Education Staff (1)

- Teachers (8)

Nonprofit organizations (2)

- Executive Director (2)

- Program staff (3)

Parents/Community Members

- Parent Coordinator (1)

Parents (5)

\section{Data Collection}

- Interview audio and transcripts

- Focus group audio and transcripts

- Policy documents and program materials

- Site visits to schools and non-profit organizations

- Field Notes 


\section{Data Analysis}

All interview and focus group data were transcribed verbatim in the language used by respondents (e.g., English and/or Spanish). All responses were organized according to emerging themes related to the research questions and, using MaxQDA software, two transcripts were coded independently by the co-researchers. After the co-investigators met to compare and discuss themes, they decided on a coding protocol for the remaining transcripts. Finally, after the remaining transcripts were coded independently by each co-investigator, final coding decisions were made collaboratively. The codes generated from the transcripts were mapped onto the research questions, with careful attention to differences in themes as expressed by the participants. Multiple data sources enabled triangulation with multiple perspectives captured on each issue. 


\section{Appendix B \\ Methodology Overview}

\section{Research Questions}

1. What does it mean to engage in community-based research that aims to humanize and decolonize those of us engaging in research and the communities we belong to?

2. How can counter-storytelling serve as a medium and methodology to resist deficit frameworks affecting ourselves and our communities?

Participants (6)

Graduate students (2)

ESOL Education Specialist (1)

Language Arts Teacher (1)

MTSS Coach and Learning Resource Specialist (1)

Graduation and MTSS Coach (1)

\section{Data Collection}

- Pilot study corpus (interview and focus group audio, transcripts, field notes, policy documents)

- URBAN data analysis meetings (audio and transcripts)

- URBAN convening field notes

- Electronic correspondence (post-URBAN convening)

Astrid and Molly brought salient excerpts from the pilot study corpus to the URBAN convening and the team discussed emerging themes that surfaced during data analysis sessions. The pilot study corpus excerpts included data from individual and group interviews with school administrators, teachers (including participants themselves), and district personnel as well as a focus group with mothers. The process was meant to encourage all participants to make connections between the data and our personal experiences as teachers, researchers, Latinx individuals, and/or allies. Our next step was to engage in individual writing using the prompt, " $I$ probably shouldn't be telling you this, but....". This prompt was suggested by our mentor, Michelle Fine, and was meant to leverage our emotions and perspectives through letters written to recipients of our choosing. Moreover, the prompts encouraged vulnerable, honest responses (the things we only dare tell ourselves) challenging dominant narratives about teaching, teachers, Latinx Puerto Ricans, and/or displaced Puerto Rican students in the aftermath of Hurricane María. We sat at a table together for 10 minutes to write our letters individually, and we read our stories aloud to each other. This provided an opportunity for a dialogic process that centered the different voices and experiences represented in our group and facilitated the co-construction of meaning through a discussion of the commonalities and differences across our narratives. 


\section{Data Analysis}

A few months after writing our letters, each participant re-read the counter-stories on our own and wrote responses recording how we felt after revisiting them. Each team member also described common themes identified across the letters after reading them. By gathering individual and collective responses to the letters and letter-writing process via email, Astrid and Molly traced three major themes across our collaborative sense-making: a desire to resist systems of white supremacy and coloniality by positioning teachers, displaced students, and their families as agents rather than victims, a sense of (un)belonging that transcends or exists beyond the storm's landfall, and the power of counter-storytelling as a humanizing, liberating act. 